\title{
Impact of Museum Pedagogy on Educational Environment
}

\author{
Nataliia Filipchuk
}

The article is dedicated to development and consolidation of museum pedagogy in educational environment, growth of its impact on the young generation with the purpose of preserving national identity, encouraging love and respect to cultural heritage of the people. Use of a museum in educational process is seen as a novel technology of personal development by means of art. Forms and methods of interaction between participants of cultural-educational process, peculiarities of use of interdisciplinary and polyartistic approaches in building a cultural-pedagogical dialogue have been generalized. The article emphasizes that a significant factor of museum pedagogy is pedagogical mastery of workers of a cultural institution (museum) and an educational institution (kindergarten, school, college, gymnasia, university etc.). The phenomenon of «pedagogical mastery» itself in museum pedagogy is the main prerequisite for a productive dialog, communication with visitors.

Keywords: museum pedagogy, museum, education, upbringing, culture.

\section{Introduction}

Modernization of Ukrainian education, consolidation of the role of a museum in the life of modern society have made it necessary to perceive and evaluate the vast cultural heritage accumulated by humankind in a new way and form a need to communicate with it. Pedagogy, as science with certain theories and values, does not exist in isolated space, thus all processes which take place in culture have their impact on it. Currently pedagogy is getting more oriented towards humanistic, democratic and cultural values, anthropological approach to the variety of cultural achievements is gradually getting a higher priority. The system of national education is witnessing active changes, not only normative and structural, but also content-related. Integral approach to use of certain forms and methods of pedagogical influence is being widely used, its efficiency is being worked on.

Interaction of a pre-school educational institution, school with museums, theaters, enriches theory and practice of educational-instructional 
process, contributes to formation of the system of values of the young generation. In these terms both museum and theater can do a lot for modern education. Self-awareness, self-development, self-fulfillment of an individual are much more successful if a child sees examples and paragons in culture and art, if a child makes a choice, organizes and researches on his/her own. Thus, democratic communication with the world of museums contributes to formation of the outlook foundation of a personality.

\section{Theoretical basic}

The received research outcomes helped define contact areas of museum pedagogy in the system of pre-school, school and higher education, specify functions and clarify main directions of development of museum pedagogy in modern society. Particularly important are individual elements of the system of educating children by means of museum pedagogy, its impact on formation of nationally conscious personality. It has been stated that peculiar attention from the side of education should be paid to popularization of museums, search of new forms of cultural-educational interaction, which is impossible without formation of society's respectful attitude to the values of museum culture, increase of its social status, building positive motivation of citizens, especially youth. Active implementation of museum pedagogy in educational process will contribute to overcoming of negative frequent practice of disintegration of cultural environment and educational institutions.

\section{Discussion and research results}

The statement saying that «a museum, as modern museum experts see it, is a special educational environment» is an axiom and cannot be discussable for Ukrainian pedagogy (Voronina, 2011). Significance of a museum lies not only in collecting, studying, storing, caring for a depositories and properties, but primarily in «transferring» museum culture to the society. Demand for it also created when one learns their history, spiritual and material cultural heritage of the People and the Humankind and thus is able to forecast their way to the future. Besides, the world in the XXI century is getting more and more contradictory, aggressive, with growing tendencies for threats and challenges. Political and technological solutions for providing stable growth of the world are not enough to humanization of the Human with efforts to establish the universal principle of ethical responsibility «for all which is alive».

That is why the process of increasingly persistent interference of culture in the content and philosophy of education is natural since through 
culture and education problems of progress and humankind survival will be solved. This topic is getting even more sensitive in connection with the EU passing the strategic «Green Deal» (2019) which demands from all communities and states moral-ethical standards of behavior in HumanNature and Human-World relationships.

Cultural paradigm in education is turning into one of the most important directions of Human «humanization» strategy. This point is quite topical for educational policy if you take into account that the European states in the XXI century place special emphasis on the role of culture and art. Society development, educating young generation is seen in the context of active implementation in the content of culture of cultural values, improvement of school art education. Culture is becoming that effective means with the help of which identity, international dialogue, understanding between states and peoples are kept and strengthened. A new task arises not only to widen a range of competencies for the young by creating better conditions for creative development, but also to educate self-respect and respect to «different» in the environment of European and world communities. All these stipulate need for activating cooperation of educational and cultural institutions, more persistent implementation of principles of culture compatibility in kindergartens, schools, namely through museum pedagogy as well.

With this purpose in mind in 2006 the European Parliament and the Council of European Union approved Recommendation on Key Competencies for Lifelong Learning (European reference framework) which include «cultural awareness and expression» (Recommendation, 2006).

«White Paper on Intercultural Dialogue» by the European Council (2008) emphasizes a significant potential which is held by cultural and educational institutions: museums, monuments, kindergartens, schools. The fact of the European Parliament passing the resolution of art education acquiring a mandatory status on all educational levels actualizes systematic introduction of museum culture, education, museum pedagogy in general European educational environment for more effective formation of key competencies by pupils.

It is a positive fact that in many European countries the ideas mentioned above are already being incorporated in school and pre-school curricula. For instance, a Romanian pre-school presupposes development of art education among young pupils through music, art, motivation talent show events being in a constant interaction with museum culture. What stimulates it (active cooperation of school and museum) is also syllabi of optional courses in Romanian language, national culture, civilization and mass use of information and communication technologies in modern study 
process. European educational systems focus greatly on balance of real and humane (humanitarian) education and thus give opportunity to actively introduce in its content art classes, museum culture. In Poland a lot of attention is given to studying integrated art subjects (since 2001). In grades 1 through 3 music classes are held together with Polish language classes, folklore classes, dance classes, nature classes (songs about certain seasons) etc.. Main school curriculum has an integrated course in art and in gymnasia pupils study Polish culture for three years. Hungary can boast profound studying of art subjects. Music, choreography, acting, painting, filmmaking subjects in elementary school (main study curriculum) take 16\% and in high school - over $10 \%$. In high school gymnasia curriculum a music history class is mandatory. Extremely popular direction in art on all levels of school education is choir singing. Integrated studying in Swedish elementary schools moves to secondary schools, where the subject of art is studied over 3-4 hours. It is clear that all above said in structural, contextual and quantitative ways does not mean the mentioned approaches are optimal since paradigm shifts always take place, preferences change, new times call for new demands, challenges and needs. Still it is obvious that one cannot leave out, ignore culture (spiritual and material), experience, knowledge, beauty created by humankind. A person's intentions and actions (according to Christian ethics too) have to acquire not only state of god's acts, a god given art, but also a culture act. Culture is becoming increasingly in higher demand as a civilization valued for education. In a narrow sense, it is a key element of European reference framework of main competencies which are needed by people for self-fulfillment, social life and social unity. In a broad, global context, it is necessary for humankind to survive, interact and progress. It is worth mentioning that humanization of the world and own «I» has to be supported by both deep all-human values and values of national cultures, since even in the circumstances of globalization, integration and neutralization of many entity peculiarities needs for mutual learning, connecting, cooperation of local and national units will grow. As the Nobel laureate Czeslaw Milosz said, «it is a friendly competition of nations and each of them, even the smallest, is essential because together they are like rainbow colors...» (Milosh, 2015).

The above mentioned processes of art education, strengthening of culture constituent in the contents of education, starting from pre-school and elementary, prove that a required prerequisite for its improvement are museum culture and education. This phenomenon became visible in the early XX century in cultural-educational and science environment, when the new notion of «museum pedagogy» came into practice and theory connected with such German pedagogue-scientists and art experts as A. Lichtwark, A. 
Reichwein, H. Freudenthal. In 1913, a noticeable event of international level took place in Mannerheim - the conference «Museum as an educational institution». Two decades later (in 1934) a German scientist K. Friesen was the first to introduce this term in science vocabulary. The newly created branch aimed at transferring cultural experience on the grounds of interdisciplinary and poly-fiction approaches through a pedagogical process in the circumstances of museum environment. Obviously, this discipline developed through museum culture on the intersection of culture studies, museum studies, pedagogy and psychology and aimed at activating educational and instructional work, starting from children of pre-school age and elementary school. It had universal character and good traditions behind, having started its history from first children's museums opened in the USA in the late XIX century. The first children's museum was opened in 1899 in Brooklyn (New York, USA), on the territory of Ukraine the founder of such institution in Kharkiv in 1920 became F. Schmit. Museum education in Ukraine had been developing long before this official date, though. On the Ukrainian lands, divided by two empires (Russia and Austria-Hungary), despite all difficulties, museums were being built. It was mainly thanks to the aware segment of the population, public organizations, that collecting and studying of cultural heritage was organized. Museum studies were seen as an essential constituent in preserving cultural and historical values, formation of national consciousness, intellectual, spiritual, aesthetic development, especially of the young. In the 1870 s, a valuable museum collection was made up at the People's House in Lviv. From the beginning of its compilation in 1868, antiques were collected by «Prosvita», Stavropihiyskyy Institute and Shevchenko Scientific Society in particular. In the 1870s, this scientific and informative activity was strongly supported by I. Franko, M. Hrushevskyy, F. Vovk, V. Hnatiuk and many others. Later three museums were founded on this ground: a cultural and historical one, a nature science one and a museum of historical and military artifacts. Metropolitan A. Sheptytskyy created a church museum in Lviv in 1905 which was reorganized three years later into a national museum. Similar situation could be observed in other cities of Galicia, Bukovyna, Volyn and Transcarpathia. The following museums were created: in Chernivtsi (folklore); in Peremyshl (painting gallery); in Stanislav (seminary), as well as in Ternopil, Kolomyya, Mukachevo, Zalishchyky, Lutsk, Truskavets, Ostroh etc.

Famous Austrian researcher of the XIX - early XX centuries R.F. Keindl in his work «History of Chernivtsi» describes the current state of affairs in museum activity of Bukovyna, «Since University was opened in 1875, social life has had various new impulses which are very useful for 
scientific research of the motherland. One outcome of such intentions is a regional library founded in 1851 and a regional museum opened in 1863. In 1888 an industrial museum was opened» (Kaindl, 2015). Museum institutions were a center of attention of famous educators, pedagogues, writers, sponsors, church leaders. Even then certain cooperation between newly-created museum institutions with educational institutions was observed.

Modern museum pedagogy implies different kinds of interaction of educational institutions with museums, as well as among participants of a cultural-educational process. Tours, lectures, museum classes, conferences, seminars, readings, presentations, meetings, museum workshops, «Open doors» days, museum quests, performances are used depending on the category of visitors, museum profile and mission, purpose and tasks which are being pursued by the museum or educational institution. A significant and defining marker is age category, as well as education level, and even place of residence. Ukrainian scientists who research the problem of a museum as an educational environment state that certain acceptable kinds of interaction are always formed according to characteristics of museum audience. In the workbook «Museum as a communicative and educational environment» (2017) it is stated, «For adult audience the museum offers the followings kinds: lecture, consultation, meeting, presentation, concert, memorial, conference, colloquium, training. For children the following events are offered: museum class, museum quest, interest group, study class, workshop...» (Verbytska, 2017).

Peculiarities of functioning of principles and directions of museum pedagogy arise on all stages, starting from a pre-school one and up to university and post-graduate ones. Level of professional competencies and requirements to pedagogical mastery are in high demand both in work with children of pre-school age and students or graduates.

It is worth mentioning that museum studies is being actively introduced in pre-school education system, so knowledge of young children's and their parents' psychology, analysis of socio-cultural environment, ability to use adequate technological and methodological tools and means, fulfilling concepts of educational character are becoming significant constituents for improving interaction in cultural-educational environment. This is encouraged by the purpose and a number of tasks set to museum pedagogy, the main one among which being creating high-quality conditions on the level of pre-school education for development of personality by means of versatile and multifaceted museum activity. Having analyzed Ukrainian experience of best pre-school educational institutions in terms of their interaction with museums, one can single out a number of 
principal tasks which need to be addressed within the model «museum pre-school educational institution». Among them will be the following: a) forming in children positive attitude to cultural-historical heritage by means of museum pedagogy; b) forming an image of a museum as a keeper of cultural-historical heritage artifacts; c) development of interest to museum exhibits; d) broadening and deepening children's knowledge by means of museum culture e) involving children of pre-school age in forming and keeping museum exhibit fund; implementation of active kinds of work by teaching staff; conducting cultural-educational work among children, parents, pedagogues, public; forming Ukrainian identity etc (Voronina, 2011).

Analysis of activity of a number of pre-school institutions in Ukraine shows development of positive tendencies in the area of museum pedagogy which are formed thanks to implementation of progressive pedagogical practices, scientific ideas, those of Ukrainian and European pedagogues in particular, integrated approaches to using museum science, pedagogy, psychology and culture studies knowledge. A positive effect is that on the level of interaction of museum culture and a pre-school educational institution a significant component of search and research activity is being established. Such direction, despite peculiarities of pre-school children's age and psychological state, has become an essential constituent of child's development tanks to implementation of best samples of national and foreign education experience, the system of pre-school education by Sofia Rusova in particular. On all stages of search and research kind of work forms and kinds of museum communication, content component had as support thorough scientific-methodological grounds, high-quality knowledge of children's psychology, effective technological mechanisms with the purpose of waking interest in child's nature to culture in museum environment. An obvious theoretical and practical outcome for pedagogical staff of pre-school educational institutions has become thoughtful and systematic application of this scientific-pedagogical heritage which resolves an eternal conflict of the optimal balance of rational and emotional components in the early period of personality formation. It is an essential part in the system of activity education process, interaction of a kindergarten and a museum.

Though Sofia Rusova did not formally cover the notion of «museum pedagogy» in her pedagogical work, her ideas and conclusions are very reasonable and topical for the modern period. They give understanding of optimization of contents, volumes, value characteristics in the process of child's entering the world of museum culture, educational-instructional environment. She wrote, «An interesting question arises before us after we 
have proven to ourselves that education is needed: what exactly should claim the most of our attention - body, feelings or mind?» (Rusova, 1996). Then she furtherly develops her idea that the two directions, the two opinions of the priorities for person's education had been coexisting in pedagogy since long ago. The first one focused on determining significance of mind, intellect, thought, cognition; the other one, on the contrary, had development of will, emotions, feelings as its priority. Both these tasks are in fact crucial in personality formation within the idea of development of a person, a citizen, a professional. They are in an unbreakable union, mutual dependency and both contribute to personality development. All social institutions, starting from family, school, church, community, in one way or another, to a certain extent, possess the potential of impacting a person from the youngest age. Museums, culture institutions, school take up a prominent place in this process. A museum, as no other institution, in cooperation with an education institution, has a unique potential to considerably influence a person's intellectual-emotional growth while enhancing, assisting this spiritual need by «culture material» a museum holds. Thus, the need of society, family, school, personality stipulates the contact, connection, interaction with those social institutions which possess the ability to «feed» culture. What is important, «culturing» as a result of interaction of museum environment and a visitor, can take place on any stage of human evolution. One should support the approach which says that educating personality is necessary (and possible) starting from youngest age when basic psychic reflexes are expressed and emotions, psychomotorics, impressions are not impacted by considerable defects and deformations. Rusova says, «in these years children are most open to impressions and one has to take care of those impressions, encourage all abilities and provoke independent thought in order to process all the impressions, satisfy activity need and educate good social feelings. In this period a child perceives more than he or she can in later years...» (Rusova, 1996). Thus, Rusov's pedagogical concept deals with an important aspect of educational-instructional, cognitive process in which a child has to be involved since early, pre-school age. The abovesaid is a weighty reason for justifying implementation of the principles of museum pedagogy in the system of pre-school education. Engagement of cultural, artistic, ethical and aesthetical contents contained in museum environment is reasonable and has its psycho-pedagogical grounding. Practical experience acquired by numerous Ukrainian pre-school educational institutions proves quite high efficiency of educational process built on cooperation and interaction with museums which were created and are functioning both in educational institutions and outside them. 
This tendency, aimed at activation of educational work with children of pre-school age through museum culture, has a universal character and good traditions, having started its history from first children's museums opened in the USA in the late XIX century. The practice of culturaleducational interaction on pre-school education level is widely used in neighboring countries - Romania, Poland, Slovakia, Hungary... Contact with culture, history, art, offered in those forms and by those means, which take into account age and psycho-physiological peculiarities of pre-schoolaged children, speeds up and increases intuitiveness of child's sense, process of its transformation into interest and motivation. The more clearly and interesting a museum subject, exhibit, display is presented, the more masterfully a museum pedagogue as a psychologist, methodologist, museum scientist builds a dialogue and interaction with young visitors with subjectsubjectivity in the niche of museum pedagogy, the more chances a museum gets to be «the third home» for family and children.

Of course, introduction of museum pedagogy in pre-school education system possesses lots of constituents of social, psychological, organizational-pedagogical directions. First and foremost, it is important to resolve the issue of engagement of pre-school-aged children in social education, which currently equals to $56 \%$ in Ukraine. Another important aspect is the problem of accessibility for population, including young and pre-school-aged children, to cultural institutions (museums). Not enough public attention is paid to the issue of introduction of museum pedagogy, with consideration for positive foreign experience in this area. Contents of pedagogical education needs improvement according to the requirements of the time, and systems of national education require strengthening of culturological content thus modernizing the system of training and retraining of teaching staff, museum experts within global processes of education «culturing». Children have their natural interest, so they constantly need new knowledge, impressions, hobbies. Thus, big-scale socially significant task of modern pre-school and elementary education is to optimally engage in educational-instructional process 4,000 museums controlled by Ministry of Education and Science of Ukraine, as well as most industrial, departmental, communal, national ones, the majority of which are aimed at children's and youth audiences.

It is true that one needs to create and know such places and museum spaces which could be interesting and at the same time informative for children. For effective introduction of museum pedagogy in instructional and educational process it is important to correctly select a cultural institution - a museum which possesses the quality of being in demand among children and youth. For instance, in Kyiv among them there is 
«Magnet» interactive museum - first in Ukraine educational and entertainment center for children, created for studying (in the form of a game) science laws and natural phenomena. The main part of this interaction is children's active participation in a scientific experiment, and every exhibit, museum item, offered for examination, is accompanies by an explanation, a dialogue interaction among a museum expert, a pedagogue and a pupil. Same approach is used for tours, museum classes in «Pyrohovo» ethnographic museum, «Ukrainian Village» ethnographic park museum where six historical-cultural regions of Ukraine are presented: Middle Naddniprianshchyna, Podil, Polissia, Slobozhanshchyna, South and the Carpathians, «Savka Hamlet», «Sea Fairytale» Oceanarium, Kyiv Museum of Railroad Transport, «Eden Garden» display at the National Botanic Gardens named after Hryshko, Metropolitan Museum. Especially popular are popular scientific works in the National Nature Sciences Museum of the National Academy of Sciences of Ukraine, which is over 100 years old and where over 30,000 exhibits are currently on display telling about life on Earth, evolutional processes, peoples which populated Ukraine in old times, as well as Kyiv Planetarium, astrological school, astrological art room. Practice shows that emotional impact on children is quite strong since the «Great Zeiss IV» device is installed there which lets see around 7,000 stars of Northern and Southern hemispheres. It is essential for educationalinstructional and creative process that the planetarium has an astrological art room (an art room for space painting) for children aged 4-11 and an astrological school for children aged 6-11. The planetarium conducts classes on astronomy, geography, nature sciences. A space café, a play zone, a spherical cinema where one can watch starry sky demoes with spherical movies, digital slides, videos etc. create artistic and dialogical atmosphere in the environment of museum culture.

Original forms and methods of educational work are typical of cultural-educational interaction of a pre-school educational institution, a school and a museum in Lviv museums (state nature sciences museum, glass museum, «Secret drugstore» interactive museum, museum for people's architecture and everyday life items, «Arsenal», «Under Black Earle» drugstore museum which is the oldest and the only acting in Ukraine and Europe drugstore and museum); Kharkiv museums (nature museum, railroad museum, museum of scientific discoveries, doll museum, historical museum, literature museum, maritime museum, planetarium, House of Scientists where science clubs for children and adults work); Odesa museums (museum of interesting science, paleontological museum, wax figures museum, football museum, museum of anchors, Odesa observatory, geological-mineralogical museum, Odesa movie studios, 
museum of modern art, museum of fleet, historical and culture museum, museum of rare books, art museum, literature museum, numismatic museum, archeological museum «Steppe Ukraine») and many other cities of Ukraine.

For effective interaction of a pre-school educational institution (school) with museum environment it is important to create a model of optimal communication of the museum with users for each particular case, which is one of the most essential issues of museum pedagogy. A museum status, its intellectual and content possibilities, visitors" «quality» stipulate the level of precision. Depending on specifics and conditions of museum environment, a degree of scientific information, accessibility, number of details, educational impact, motivation of a child (pupil). In connection with this, it is necessary to hold an important and essential approach when museum communication, that is a «conversation», «dialogue», «expression» have to match interests, level and abilities of the consumers (recipients). «Scissors» (mismatch) between two interdependent and interrelated subjects in the process of interaction lead to failure in achieving the goal. Even high level of professionalism in knowing a certain subject, problem or phenomenon cannot guarantee success in perceiving cultural phenomena. Too «intellectualized» information and a professional's «speech» not always can be «heard» by a child. The point is not to ignore principles of scientific approach and objectivity, but to consider physiological, age, psychological, intellectual, social characteristics of the visitors. Thus, it is about keeping to the crucial pedagogical principle - accessibility. Ukrainian Pedagogical Encyclopedic Dictionary defines it as follows, «accessibility (feasibility) is a didactic principle according to which studying is built with consideration for pupils' level of preparedness, their age and individual peculiarities. According to this principle, pedagogically grounded programs, workbooks and teaching methods are made. The precondition of conscious knowledge acquisition and activity is study material accessibility...» (Honcharenko, 2011).

Museality is able to work if main pedagogical principles are taken into account while communication is performed. Not only the accessibility principle should be considered during a contact, a meeting, a dialog with children, young pupils who do not possess proper life experience. Subjectsubjectivity in the process of interaction is also essential. As famous European museum experts have it, «communication is transfer of information with the help of signs or systems of all kinds which requires an addressee...». and cannot only be seen as simple transfer of information (Vaidakher, 2005). Effect of communication depends on character, style, interaction method between (minimum) two subjects - a speaker and a 
recipient. Thus, on the level of both general and museum pedagogy cooperation and collaboration are required. This is a general didactic and methodological rule that is applied to all categories of an educational process. Productive action, interested position, mastery in perception or transfer of knowledge information will always not be enough from one side only. It is necessary to create the atmosphere of subject-subjectivity in the process of cognition, studying, instructing, educating. Famous Ukrainian pedagogue I. Ziaziun, while grounding ways and means for achieving scientific-pedagogical and educational outcome, wrote that «for motivating a cognitive process and forming the outlook one should encourage education turning into self-education, studying into self-studying, education into selfeducation. That is why mastery of a pedagogue (museum pedagogue author's remark) is stipulated by three constituents: theory, technique and methods of working on study material, its organization and implementation into action» (Ziaziun, 1997). Without knowing «the material», which should be understood both as museum culture and people - museum visitors, it is impossible to form the atmosphere of cooperation, process subjectsubjectivity, pedagogical interaction. Impact has to be made through cooperation, taking into account significance, topicality of the museum material, as well as methods and forms of «communication» between a museum expert - pedagogue and a visitor. A pedagogue becomes similar to an actor who has to carefully consider of number of criteria which should be applied when working with people. So, as famous European museum experts believe, one has to adhere to minimum four elements during parties interaction: «quantity (as informative as is needed), quality (truthfulness), relevance (only what is important for communication), manner of speaking (be clear)» (Ziaziun, 1997). When a deep layer of museum culture is on one side and a museum visitor is on the other side, especially when the visitor is a pre-school-aged child, a schoolchild, who came to the said environment for cognition, excitement, research or pure satisfaction, possibly even without motivated wish, then it creates high requirements to a pedagogue, a museum expert. Even their natural abilities and potential do not guarantee success. Work and self-improvement, which mill make them masters, are required. Only such masters are able to awaken a thought, persuade, excite, invoke aesthetical and ethical, citizen's feelings. Pedagogical goals are often fulfilled through performing artistic action, as a professional combination of many creative features of a teacher, in order to impact Person's feelings, though and spirit. That is why it is logical to compare performing and pedagogical professional mastery. V. Nemyrovych-Danchenko wrote, «Performing art is unbelievably complicated, and the things that let an actor possess audience's attention are versatile: contagiousness, personal charm, 
intuition, speech, plasticity, gestures beauty, ability to embody a character, work, love to what they do, taste etc.?» (Nemirovich-Danchenko, 1953). For education, manners, mastery of a pedagogue there are no trifles, secondary things, since pedagogical culture consists of a full range of quality and required characteristics. It is worth understanding that successful «transfer» to community of museum culture can only be performed with high pedagogical culture.

Grounding on the underlying principles of pedagogical classics, one should single out significant aspects of features a museum pedagogue has to have for effective cooperation. A mandatory rule of behavioral norm is continuous improvement a pedagogue has to do in various facets of professional action, in spite of natural potential. In order to pursue this goal, not only assiduity, but also moral-ethical education, internal and external «neatness», «high culture» have to make an essential element of the individual characteristics, which will considerable enhance subjects' interaction. In connection with the above said, criteriality in professional activity and pedagogical mastery assessment has to be widened because a relationship, communication, as well as impact of a subject of museum environment, have to presuppose multicomponent action - intellectualcognitive, psychological, moral-ethical, methodological-technological, aesthetic, outlook-forming, which are interconnected. Compatibility of a pedagogue and a pupil is built on similar qualities and impacts a pre-school child, a pupil, a student morally, aesthetically, intellectually, spiritually. During the communication it is necessary to possess good vibes, kind intentions, creative mood, natural attitude and sincerity. Social demand, «collective mood» also considerably influences assessment of phenomenon, object or fact essence. Natural subjectivity in attitude to museum exhibits is defined by: a) qualitative characteristic of a museum subject; b) level of a museum expert (a pedagogue) preparedness; c) a visitor's individual state; d) social needs, challenges of the time etc. Specialists claim that «one subject can be semantically described in a number of ways, not only depending on the mood of an individual who is looking at it, but also on the society which is using it and its collective thoughts». In fact, interpretative exhibiting of authentic (and not only) objects as one of the main communication directions is mainly stipulated by particular social-political regime, tasks and goals of the social environment which created and is accompanying functioning of the museum. Having defined an outlook-forming, ideological and knowledge paradigm, having provided selection, audit and storage, society (state) has to provide access to cultural values, to make contained information public and open. 
It has been practically proven that communication can be either ecological, that is successful, or unecological (unsuccessful), conflictogenic, destructive. A museum pedagogue has to possess lots of qualitative characteristics and communication sides, namely: a) communicative, when exchange of information takes place between those who communicate; b) interactive, when organization of interaction between individuals takes place; c) perceptive, when process of intersubjective perception and cognition takes place, with communication and the atmosphere of mutual understanding.

In addition, quality of another very important constituent has to be ensured for reaching optimal communication - museum display. Firstly, a museum collection (fund) has to hold such resource of cultural values, museum exhibits, on the grounds of which one can compile displays of various kinds and themes. The point of existing and functioning of this social institution lies in its ability to display available objects and thus prove that they are stipulated by social or individual interests. That is why museum display is a dominant element of activity and functional interaction among museum subjects. This expressive means against the background of various kinds of supportive museum forms of sharing knowledge, information, valuable elements is the most essential and has no alternatives in the context of achieving an educational goal. Museum display is a dominant factor in the system of communication process. The quality of its compilation and compliance of its presentation for public display with the principles of pedagogical mastery determine formation of a person's consciousness as a motivational ground for an action, development and establishment of the system of values, acquisition of new knowledge, support of a citizen's position. While the main mission of the museum as a social and cultural institution is development of a person, society, state according to the established values, museum pedagogy is an optimal means (tool) for this action through contact and interaction with museum environment, museum exhibits. As a pedagogical subject, it embraces a wide range of education aspects - intellectual, humanitarian, spiritual, ethical, aesthetical, civil, ecological (Vaidakher, 2005).

Effectiveness of museum pedagogy in action in pre-school, school or museum environment increases firstly on condition of an optimally compiled display which proves understanding the topicality of certain problems and tasks; secondly on condition of proper level of preparedness of museum employees (pedagogues) in broad context; thirdly on condition of certain potential of cultural-historical values of a particular museum collection as a basis of display presentation. Such displays, which are the reflection of challenges of the time, social requests and needs, have been corrected and transformed by a shrewd museum pedagogue, are able to 
«speak» to the visitors (pupils). The mentioned forms of activity (interaction) can ensure a high-quality result in the case when a museum tour guide, a teacher will be able to provoke in certain audience motivated interest while forming a subject-subjective relationship in the process of phenomenon, fact, tendency studying and cognition.

Thus, concluding from what was said above, it is necessary to single out in this context an extremely important factor of museum pedagogy pedagogical mastery. One should consider significance of this qualitative characteristic for an employee of both a cultural institution (a museum) and an educational one (a kindergarten, a school, a college, a gymnasia, a university etc.). In museum pedagogy such phenomenon as «pedagogical mastery» is a main sign that communication, a dialogue with the visitors can be productive. A communicative function is becoming a poor and ineffective one if in a particular educational-instructional situation a teacher, a pedagogue, a tour guide do not possess mastery of using methods and means of pedagogical interaction.

Most profound and systematic knowledge requires from a pedagogue skilled reflection since even mastering technologies does not makes one a master. In order to become one, it is necessary to possess personal professional uniqueness, have own activity style, conceptual professional thinking and outlook. High mastery is a prerequisite in the process of transferring to a subject knowledge and value attitudes, which find their place in spiritual and material culture (national, all-human). That is why specialists in the area of museum pedagogy add to the qualitative score of «knowledgeability» «methodology» of knowledge of an employee who creates in museum environment. Criteriality of the score lies in knowledge, positions, abilities, attitudes to «somebody» and «something. A personality of those who perform communication with «others" in cultural-educational (museum) environment is evaluated from the point of view of intellect and professional competencies, technological-methodological abilities, psychological level of preparedness with clearly expressed «I«-positive concept. So, the essence of pedagogical mastery is supported by intellectual, psycho-pedagogical, methodological-technological and mandatory civic constituents. It is the connection of such qualitative characteristics of a pedagogue-museum expert, a teacher which ensures a possibility to successfully «perform a reflective management of children's development«. Another not less important function of positive psychological attitude of a museum pedagogue is internal demand for self-development, mastering new knowledge, encouraging to search more optimal forms, methods, means, technologies in cultural-educational museum environment. The higher is the 
subjects' level of culture, the more perfect is rational-emotional perception of the world.

\section{Conclusions}

Modernization of education, starting from pre-school education and elementary education, requires significant changes in the contents of educational-instructional process defined by basic national and European legislative and normative documents. It requires broadening of educational space, involvement of new social-cultural institutions in educationalinstructional activity and improvement of pedagogical technologies, especially wider use of high potential of museum pedagogy.

The key prerequisite for organization of informational, educationalinstructional, research work of a museum and an educational institution is pedagogical mastery of museum and school workers. Its peculiarities (by contents, form and methods) are defined by both museum kind or profile and target audience and their interests, as well as by social demands. Interaction of cultural (museum) institutions and educational institutions has to be based on gnoseological and axiological principles.

Modern researchers, scientists-pedagogues see the stated goals and motivations in the context of high-priority tasks of museum pedagogy, while its functionality and action are especially important for pre-school and elementary school levels of school education.

\section{References}

Honcharenko, S. U. (2011). Ukrainian Pedagogical Encyclopedic Dictionary. Second Edition. Rivne: Volyn Charms.

Kaindl, R. F. (2015). History of Chernivtsi from Earliest Times to Nowadays. Chernivtsi. Green Bukovyna.

Milosh, Ch. (2015). Ulro's Land: Essay. Kyiv: Universe.

Nemirovich-Danchenko, V. (1953) Articles. Speeches. Dialogs. Letters. Moscow.

Recommendation (2006) Recommendation 2006/962/EU from European Parliament and Council (EU) «On Main Competencies for Lifelong Learning« of December 18, 2006. https://zakon.rada.gov.ua/laws/show/994 988\#Text

Rusova, S.F. (1996) Selected pedagogical works. Kyiv: Osvita.

Vaidakher, F. (2005). General museology. Lviv: Litopys.

Verbytska, P. V. (2017) Museum as Communicational and Educational Environment. Lviv: Published by Lviv Polytechnica.

Voronina, T. V. (Ed.). (2011) Museum in Pre-School Educational Institution. From Work Experience of Sofia Rusova School-Kindergarten. Kyiv: School World. 
Law of Ukraine On Pre-School Education (from July 11, 2001) (2001). https://zakon.rada.gov.ua/laws/show/2628-14

Ziaziun, I. A. (Ed.). (1997) Pedagogical Mastery. Kyiv: Higher School. 